\title{
N-octane catalytic isomerization with aluminium and aluminium- lanthanum pillared nontronite
}

\section{(Isomerização catalítica de n-octano com nontronita pilarizada com alumínio e alumínio-lantânio)}

\author{
C. P. de Moura', M. V. S. Fernandes ${ }^{2}$ L. R. D. da Silva ${ }^{2}$ L. C. G. Vasconcellos ${ }^{2}$, \\ R. F. do Nascimento ${ }^{3}$, A. Valentini ${ }^{3}$ \\ ${ }^{1}$ Instituto Federal do Ceará, Reitoria, Campus Quixadá, Coordenação de Química, Quixadá, CE, Brasil 63900-000 \\ ${ }^{2}$ Departamento de Química Orgânica e Inorgânica, Universidade Federal do Ceará, C.P. 6002, \\ Campus do Pici, Fortaleza, CE, Brasil 60455-970 \\ ${ }^{3}$ Departamento de Físico-Química e Analítica, Universidade Federal do Ceará, Bloco 940, \\ Fortaleza, CE, Brasil 60541-970 \\ marcusvenicio2@yahoo.com.br
}

\begin{abstract}
Nontronite samples pillared with aluminium (Pt/Al-PilM) and aluminium-lanthanum (Pt/AlLa-PilM) were prepared from natural nontronite, characterized and tested as catalyst in n-octane hydroisomerization reaction. The results were compared with those obtained from the same reaction using commercial Y-zeolite impregnated with platinum (Pt-Y). Experiments with commercial zeolite show that platinum is essential to maintain the reactional selectivity of the products. The conversion capacities of $(\mathrm{Pt} / \mathrm{Al}-$ PilM) and (Pt/AlLa-PilM) were 70\% and 40\%, respectively, surpassing the Pt-Y performance of 30\%, but with the same selectivity. $\mathrm{X}$-ray diffraction data show that organic matter oxidation followed by cationic homogenization is of paramount importance for pillared clay preparation.
\end{abstract}

Keywords: pillared nontronite, aluminium-lanthanum pillars, n-octane isomerization, platinum impregnation.

\section{Resumo}

\begin{abstract}
Amostras de nontronita pilarizadas com alumínio (Pt/Al-PilM) e alumínio-lantânio (Pt/AlLa-PilM) foram preparadas a partir de nontronita natural, caracterizadas e testadas como catalisador na reação de hidroisomerização do n-octano. Os resultados foram comparados com os obtidos da mesma reação, usando zeólita Y comercial impregnada com platina (Pt-Y). Experimentos com zeólita comercial mostraram que a platina é essencial para manter a seletividade reacional dos produtos. A capacidade de conversão das amostras (Pt/Al-PilM) e (Pt/AlLa-PilM) foram 70\% e 40\% respectivamente, superando o desempenho de $30 \%$ da Pt-Y, mas com a mesma seletividade. Os resultados de difração de raios X mostraram que a oxidação da matéria orgânica seguida da homogeneização catiônica é de suma importância para preparação da argila pilarizada.

Palavras-chave: nontronita pilarizada, pilares alumínio-lantânio, isomerização n-octano, impregnação com platina.
\end{abstract}

\section{INTRODUCTION}

Open chain alkene hydroisomerization is being used as a way to obtain ramified products, basically, iso-alkanes that can be used as an alternative in combination with gasoline, among other aromatic compounds, to improve the octane index. The iso-alkanes have an octane index higher than linear alkanes and in this way the transformation is of great interest to the petrochemical industries $[1,2]$. The hydroisomerization mechanism happens first with the alkane dehydrogenation on metal surface, normally platinum or palladium, followed by a double bond hydrogenation with carbanium-ion formation, suffering beta isomerization generating a smaller alkene and a new fragmented carbanium-ion. This alkene can be hydrogenated, giving several products [3]. For the hydroisomerization reaction it is necessary the presence of a bi-functional catalyst, capable of hydrogenation-dehydrogenation, and alkene isomerization. The research for new catalyst materials is constant among scientists looking for new active sites for isomerization, normally metals in low oxidations state, supported in porous materials with proton exchange sites [3, 4]. The desired catalyst characteristics are present in natural clay; however, pillared clay combined with active sites containing noble metals are even more active. Natural clay is a lamellar mineral capable of effective cation exchange due to the negative residual charge present in its layers and sometimes also from organic residue. The organic residue is composed mainly by acids originated from chemical decomposition of plants, as example the fulvic acid, which attracts alkaline and alkaline metal cations into the interlayer region. These minerals present low acidity and thermal stability limited 
to temperatures below $200{ }^{\circ} \mathrm{C}$. The acidity and the thermal properties in these materials can be improved, if needed, by acid activation by means of pillarization [5].The acid activation increases the specific surface and gradually destroys the mineral with clay dissolution, detected by the presence of cations in solution, such as aluminium, magnesium and iron, once inside the structure, resulting in the formation of amorphous silica, extinguishing the cationic exchange property of the material [6]. The acid activated clay was used as catalyst in the petroleum refinery during the decade of 1930-40 and in organic synthesis in recent years [7].

Pillared clay is considered a new class of substrate material with large surface area covered with micropores that has captured the attention of researchers over the world for its considerable range of applications in catalytic processes, and as support for adsorption [8,9]. Pillared clay is a porous material that can be modified by the introduction of chemical compounds. It has thermal stability to work in harsh environments, transforming organic molecules into more useful ones. Pillared clay is more stable than natural clay with higher surface area. The pillared structure is capable of avoiding collapses when heated, receiving molecules in the dimension between the interlayer and pillars, [10-14] with improved reactivity [15].

In this work, two types of pillared clay were prepared from natural nontronite, using two different intercalating reagent: the aluminium polyhydroxi cation (the Kegging ion), and the aluminum-lanthanum polyhydroxi cations with $\mathrm{Al}$ :La proportion of 10:1. These pillared clays were tested as catalytic support on the n-octane hydromerization reaction, catalysed by platinum.

\section{MATERIALS AND METHODS}

Clay preparation: the clay sample was donated by "Empresa Bentonita do Nordeste" at Paraiba state in Brazil. The clay is of nontronite type with cationic exchange capacity (CEC) of 70 miliequivalent per 100 grams and chemical composition: $(63.34 \%)$, iron $(11.71 \%)$, aluminium $(10.81 \%)$, sodium $(7.62 \%)$, calcium $(4.33 \%)$ and others $(2.19 \%)$. Prior to pillarization, a treatment to remove the organic material was performedby oxidation reaction with sodiumhypochlorite $(\mathrm{NaOCl})$ solution $0.1 \mathrm{~mol}^{-\mathrm{L}^{-1}}$ and the cationic homogenation by ion exchange with sodium chloride $(\mathrm{NaCl})$ solution 1.0 mol.L-1 ${ }^{-1}[16]$.

Preparation of intercalating solution: following a modified procedure [17]. Aluminium chloride $\left(\mathrm{AlCl}_{3} \cdot 6 \mathrm{H}_{2} \mathrm{O}\right)$ 0.4 mol. $\mathrm{L}^{-1}$ solution was kept in water bath at $80^{\circ} \mathrm{C}$. Under constant stirring, sodium hydroxide 0.4 mol. $\mathrm{L}^{-1}$ was added drop wise to the aluminium chloride solution until the $\mathrm{OH} / \mathrm{Al}$ ratio was equal to 2.0 [18]. The heating was turned off and the resulting suspension was left for $24 \mathrm{~h}$ under stirring for complete dissolution of the precipitated. The final $\mathrm{pH}$ was measured as 3.8. The same procedure was used in the preparation of the oligomer solution containing 10:1 ratio aluminium/lanthanum. The final $\mathrm{pH}$ for this solution was 3.5 .
Intercalation: a suspension containing $4 \% \mathrm{~m} / \mathrm{v}$ of clay in water was kept under stirring for $24 \mathrm{~h}$. After this time, the intercalating solution was added drop wise, at room temperature with the solution concentration ten times superior to that of the clay exchange capacity. At the end of the addition, the solution was aged for $24 \mathrm{~h}$. After this period of time, the chloride ions were removed from the solution by filtration, washing with deionised water [19].

Pillaring: the powdered samples were dried and ground before calcination at $450{ }^{\circ} \mathrm{C}$ for $2 \mathrm{~h}$, with rate of heating $15^{\circ} \mathrm{C} / \mathrm{min}$. Every intercalated sample was pillarized following the same conditions of temperature, heating rate and calcinations time.

Catalytic application: the pillared nontronite was used in the n-octane hydroisomerization to evaluate the conversion capacity and the selectivity of the catalyst. The catalytic measurements were conducted in a quartz micro-reactor operating under low pressure. The catalyst quantity used in each test was $150 \mathrm{mg}$. Previous to the test, the samples were activated under hydrogen flow for 1 h at $350{ }^{\circ} \mathrm{C}$ and/or $600{ }^{\circ} \mathrm{C}$. The hydrogen/n-octane molar ratio was 30 within a flow speed of $2.49 \mathrm{~g}$ of $\mathrm{n}$-octane per gram of catalyst per $h$. The reaction was conducted at $300{ }^{\circ} \mathrm{C}$. The reaction product was monitored by gas phase chromatography (SimpleChrom II) with a FID detector and a Ciola-1 non-polar capillary column.

\section{Natural and pillared clay characterization}

Isoelectronic point (PI): using 10 test tubes of $10 \mathrm{~mL}$ capacity, different solutions of water and nitric acid and or potassium hydroxide were used to vary the $\mathrm{pH}$ in each tube from 2 to 11 . With the introduction of clay in each tube in order to find the isoelectronic point [20].

Determination of superficial proton charge: 16 g.L.- $\mathrm{L}^{-1}$ of clay suspension in sodium nitrate solution $\left(\mathrm{NaNO}_{3}\right) 2 \mathrm{x}$ $10^{-2}$ mol. $\mathrm{L}^{-1}$ was prepared under stirring for $18 \mathrm{~h}$. The $\mathrm{pH}$ was raised to 10 with sodium hydroxide solution $(\mathrm{NaOH})$ 0.1 mol. $\mathrm{L}^{-1}$ and back to $\mathrm{pH} 3.0$ dropwise with a solution of hydrochloric acid $(\mathrm{HCl}) 0.1$ mol. $\mathrm{L}^{-1}$. The amount of proton charge in the surface (Q) can be calculated by equation $\mathrm{A}$.

$$
\mathrm{Q}=\frac{\mathrm{C}_{\mathrm{A}}-\mathrm{C}_{\mathrm{B}}=\left[\mathrm{OH}^{-}\right]-\left[\mathrm{H}_{3} \mathrm{O}^{+}\right]}{\mathrm{a}}
$$

where $\mathrm{C}_{\mathrm{A}}$ is the strong acid concentration in a given point of the titration, $\mathrm{C}_{\mathrm{B}}$ the strong base concentration used to adjust the initial $\mathrm{pH}$. $\left[\mathrm{OH}^{-}\right]$and $\left[\mathrm{H}_{3} \mathrm{O}^{+}\right]$hydroxyls and hydrogen ion concentration [21].

$X$-ray diffraction: the XRD patterns were recorded in a diffractogram for polycrystalline sample Rigaku DMAXB with Cuk $\alpha$-radiation in the 5 to $70^{\circ}(2 \theta$ degree) range, for natural clay, and from 3 to $15^{\circ}$ ( $2 \theta$ degree), for intercalated clay. The scan rate was $0.5^{\circ}(\theta$ degree $) / \mathrm{min}$. Pillared and intercalated clays were measured in the 3 to $15^{\circ}$ ( $2 \theta$ degree) range, for (001) plane in order to assign the material from its peak position and format.

Differential scanning calorimeter: the general acidity of 
the clays was investigated using ammonia probe. Previously the solids were kept under vacuum at $110^{\circ} \mathrm{C}$ to remove water and gas molecules. After that, ammonia gas was adsorbed and the interaction was determined by DSC data, using clay $(10 \mathrm{mg})$ under nitrogen atmosphere, with step heating of $10{ }^{\circ} \mathrm{C} \cdot \mathrm{min}^{-1}$ from $35^{\circ} \mathrm{C}$ to $500{ }^{\circ} \mathrm{C}$ in an Shimadzu DSC-50.

\section{RESULTS AND DISCUSSION}

\section{Physical and chemical characterization}

Natural clay: the isoelectronic point is an important information because it shows the appropriate $\mathrm{pH}$ value for intercalation using the polyhydroxication containing aluminium and lanthanum-aluminium. During the intercalation process the clay particles need to be dispersed to allow the oligomer inside the inter-lamellar space. At the iso-electronic point the particles of the colloidal system present zero or near zero electric chargeand in this way the repulsive forces are eased and destabilise the colloidal
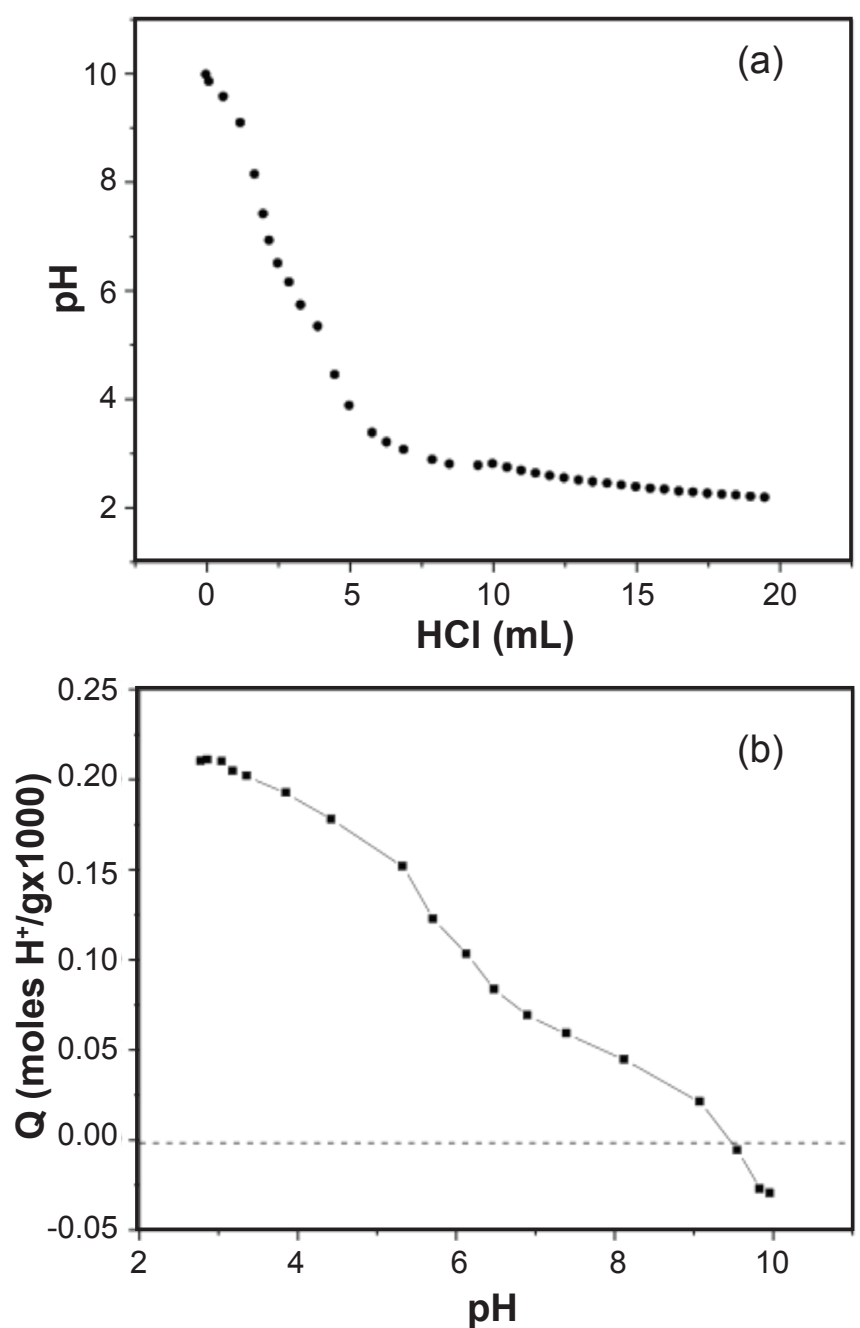

Figure 1: Nontronite proton titration curve: (a) $\mathrm{pH}$ versus volume of $\mathrm{HCl}$; (b) protonic charges on the surface versus $\mathrm{pH}$.

[Figura 1: Curva de titulação de próton da nontronita: (a) pH versus volume de $\mathrm{HCl}$; (b) trocas protônicas na superficie versus $\mathrm{pH}$.] system. Nontronite presents isoelectronic point at $\mathrm{pH} 4.5$. The $\mathrm{pH}$ in acid region is needed to turn the nontronite charge density virtually zero; it also indicates the existence of functional groups of perhaps organic matter, carboxylate groups, as well as deprotonated hydroxyl groups, which is still present contributing to the negative charge.

The acid base titration quantifies the amount of proton charge present at the surface of natural clay. Fig. 1 shows $\mathrm{pH}$ as a function of hydrochloric acid volume added and the isotherm $\mathrm{Q}=\mathrm{f}(\mathrm{pH})$, where $\mathrm{Q}$ is the amount of surface proton charge in $\mathrm{mol} \mathrm{H}^{+} . \mathrm{g}^{-1}$ of clay, with $\mathrm{pH}$ ranging from 2.0 to 10.0 .

The isotherm analysis for natural clay shows that it has an amphoteric character as $\mathrm{Q}$ is positive at lower $\mathrm{pH}$ values and negative for $\mathrm{pH}$ near 10 . The amphoteric behaviour was not expected if the clay had lamellar charges resulted from isomorphic substitutions only, since these charges are $\mathrm{pH}$ independent. Nevertheless, the charges generated by organic matter and hydroxyl groups from the lamellas of the natural material are $\mathrm{pH}$ dependents and manifest themselves as amphoteric.

The X-ray diffraction pattern for natural clay is shown in Fig. 2 and provides information about its main mineral constituents. The reflections at $7.0^{\circ}$ (plane 001), $19.7^{\circ}$, $59.8^{\circ}$ (plane 061) and $60.8^{\circ}$ (plane 060) are characteristic of nontronite clay as the predominant clay mineral [20]. The reflections at $21.7^{\circ}$ (plane 101) and $26.6^{\circ}$ plane (011), characterize silicate minerals cristobalite and quartz, respectively, as impurities on the sample. The X-ray diffraction results are in agreement with previous studies [22-24].

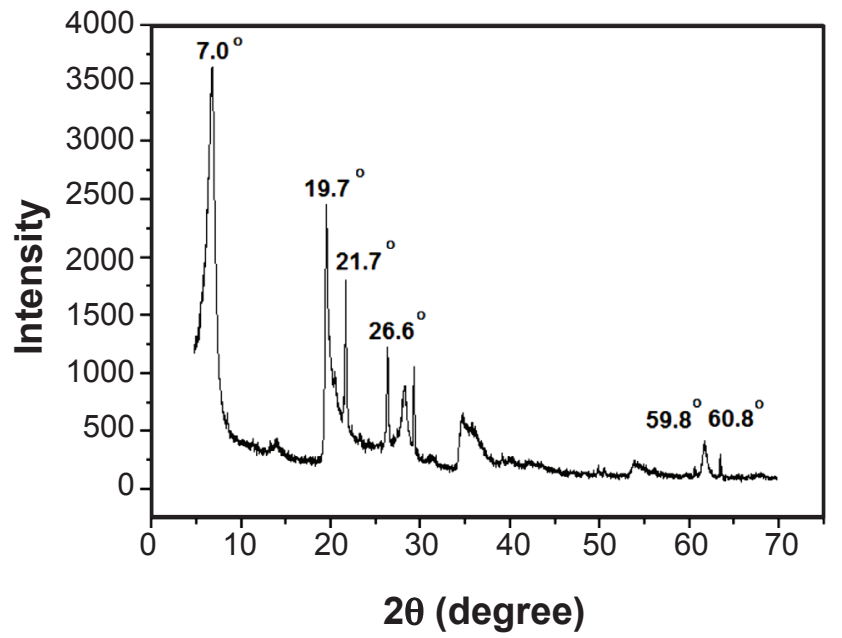

Figure 2: X-ray diffraction pattern of natural gray clay. [Figura 2: Padrão de difração de raios $X$ da argila cinza natural.]

Aluminium intercalated nontronite: previous to the intercalation procedure using the Keggin ion $\left[\mathrm{AlO}_{4} \mathrm{Al}_{12}(\mathrm{OH})_{24}\left(\mathrm{H}_{2} \mathrm{O}\right)_{12}\right]^{7+}$, the clay was treated with $\mathrm{NaOCl}$ 0.1 mol. $\mathrm{L}^{-1}$ solution in order to oxidize the organic matter and $\mathrm{NaCl} 1.0 \mathrm{~mol} . \mathrm{L}^{-1}$ solution to exchange cations in the interlayer space. Fig. 3 shows the X-ray diffraction pattern 
of natural and intercalated nontronite showing the plane (001). As expected, the peak position for intercalated sample shifted to smaller angles and to larger basal space.

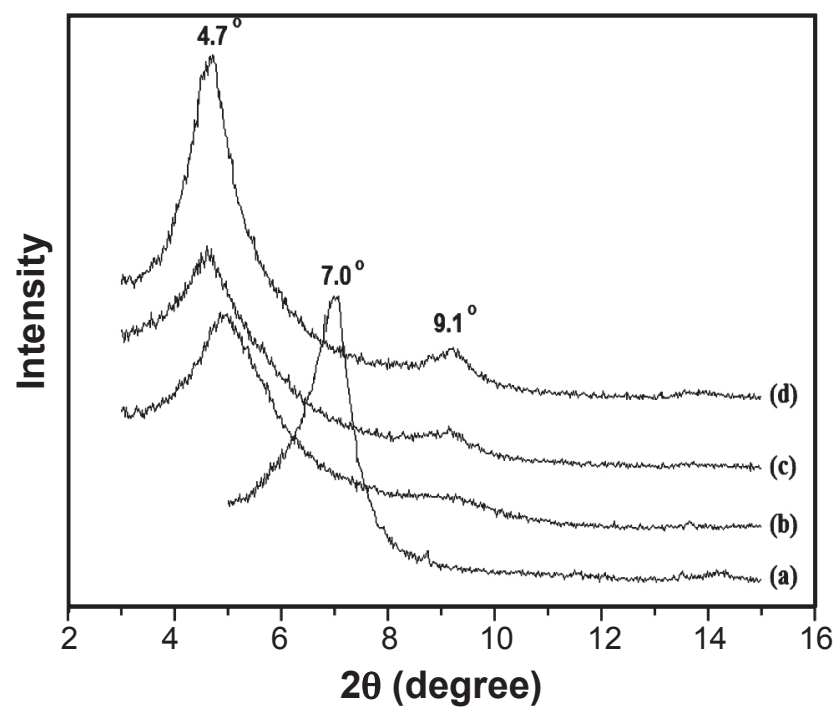

Figure 3: XRD patterns of natural and intercalated clay: (a) natural nontronite, (b) natural intercalated nontronite, (c) intercalated sodic nontronite and (d) nontronite treated with $\mathrm{NaClO}$, sodic and intercalated.

[Figura 3: Difratogramas de raios $X$ da argila natural $e$ intercalada: (a) nontronita natural, (b) nontronita natural intercalada, (c) nontronita sódica intercalada e (d) nontronita tratada com hipoclorito de sódio, sódica e intercalada.]

The diffraction peak at $7.0^{\circ}$ on the natural sample (a) corresponds to basal space of $12.52 \AA$, which is characteristic of nontronite where the interlayer spaceare filled with hydrated interchangeable cations [11, 25].The intercalation of the natural sample (b) shifted the peak to $4.9^{\circ}$ yielding a basal space of $17.74 \AA$. When the natural sample is treated with sodium chloride and intercalated (c), the diffraction peak shifts to $4.6^{\circ}$ and a basal space of $19.20 \AA$. By comparison with the intercalated natural clay, the sodium treatment does not alter the textural properties [26], but yieldd a better oligomer distribution showed by the peak with smaller width at half height and shifted toward smaller values of $2 \theta$. The best resultwas obtained with nontronite treated with $\mathrm{NaOCl}$ 0.1 mol. $\mathrm{L}^{-1}$ and $\mathrm{NaCl} 1.0$ mol.L ${ }^{-1}$, sample (d). It shows the

Table I- Structural parameters obtained by XRD for nontronite samples.

[Tabela I - Parâmetros estruturais obtidos por DRX para amostras de nontronita.]

\begin{tabular}{ccccc}
\hline $\begin{array}{l}\text { Natural and } \mathrm{d}_{001}(\AA) \\
\text { intercalated } \\
\text { clay }\end{array}$ & $\begin{array}{c}\text { Peak height } \\
\text { (counts) }\end{array}$ & $\begin{array}{c}\text { half-width } \\
\left({ }^{\circ} 2 \theta\right)\end{array}$ & $\begin{array}{c}\text { Peak area } \\
\text { (a.u.) }\end{array}$ \\
\hline $\mathrm{a}$ & 12.52 & 2814 & 0.92 & 2589 \\
$\mathrm{~b}$ & 17.74 & 1305 & 1.45 & 1892 \\
$\mathrm{c}$ & 19.20 & 1232 & 1.20 & 1478 \\
$\mathrm{~d}$ & 18.95 & 2430 & 0.92 & 2236 \\
\hline
\end{tabular}

diffraction peak position at $4.7^{\circ}$, which corresponds to basal space of $18.95 \AA$. The crystallinity can be inferred by the broadening of the peak [16] and the less intense peak at $9.2^{\circ}$ and basal distance $9.6 \AA$ for samples (c) and (d) respectively are typical of collapsed layers on nontronite [27]. Table I presents the mentioned structural parameters.

Aluminium pillared nontronite: the X-ray diffraction pattern was used to analyse the sample (d') as sample (d) when subjected to calcinations at $450{ }^{\circ} \mathrm{C}$ over $2 \mathrm{~h}$, Fig. 4 . Due to calcinations, it is observable a reduction on peak intensity related to the nontronite layers (identified with $\mathrm{M}$ on the figure). The thermal treatment at $450{ }^{\circ} \mathrm{C}$ altered the cristobalite and the quartz compositions. It was reported that cristobalite is converted into quartz with increasing temperature, and as the results shows, the peaks at $21.8^{\circ}$ and $29.5^{\circ}$ assigned to cristobalite loses intensity while there is an increase on peaks at $26.6^{\circ}$ and $50.1^{\circ}$ assigned to quartz [24]. The new observed peaks at $20^{\circ}$ and $27^{\circ}$ indicate the anortite fase formation.

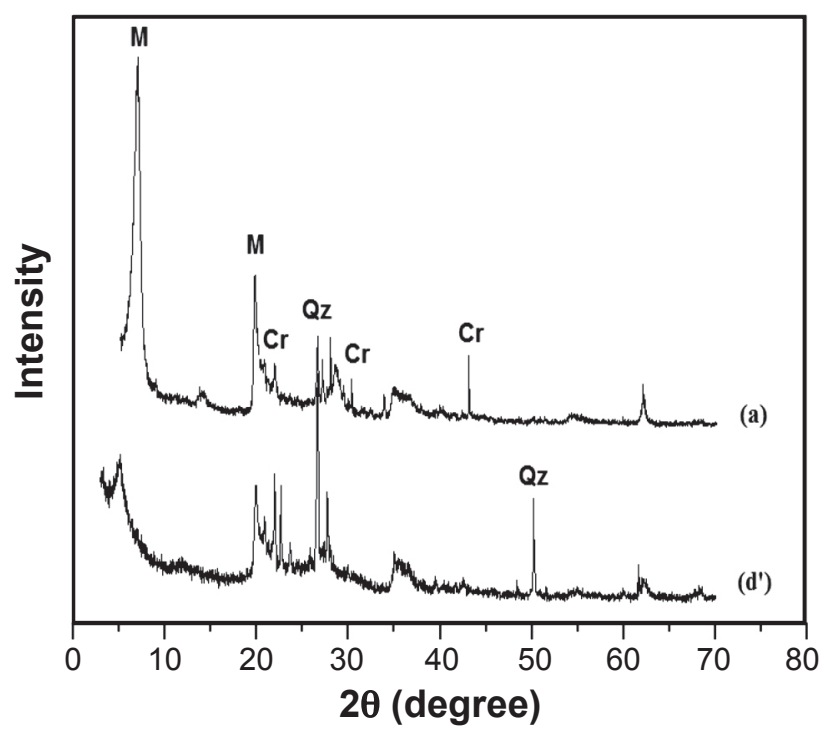

Figure 4: XRD patterns: (a) natural nontronite and (d') Al pillared nontronite.

[Figura 4: Difratogramas de raios X: (a) nontronita natural e (d') nontronita pilarizada com Al.]

The X-ray diffraction pattern on the interval $3^{\circ}-15^{\circ}$ shown in Fig. 5 refers to the intercalated nontronite samples (b, c and d). As expected, the thermal treatment needed for pillar formation also disorganise the layer packing, producing a reduction on peak intensity and a broadening of the bands together with a decrease the interlayer distance [1]. Considering the perfect randomisation of the planes, the nontronite, (d') had its crystalinity reduced by $80 \%$, inferred by the loss of intensity of the peak, however keeping the interlayer distance of $18.54 \AA$.

The regularity presented by the sample (d') reinforce the importance of the chemical process during its synthesis when treated with $\mathrm{NaOCl}$ and $\mathrm{NaCl}$. The $\mathrm{NaOCl}$ used as oxidizing agent on the removal of organic compound together with the sodium ion that homogenises the clay. As the reaction is 
performed in hot condition, the exchange of cations occurs more effectively, helping on pillar organization inside the interlayer space, consequently improving the clay resistance on calcinations. Its basal space of $18.60 \AA$ is in agreement with reported values $[23,28,29]$.

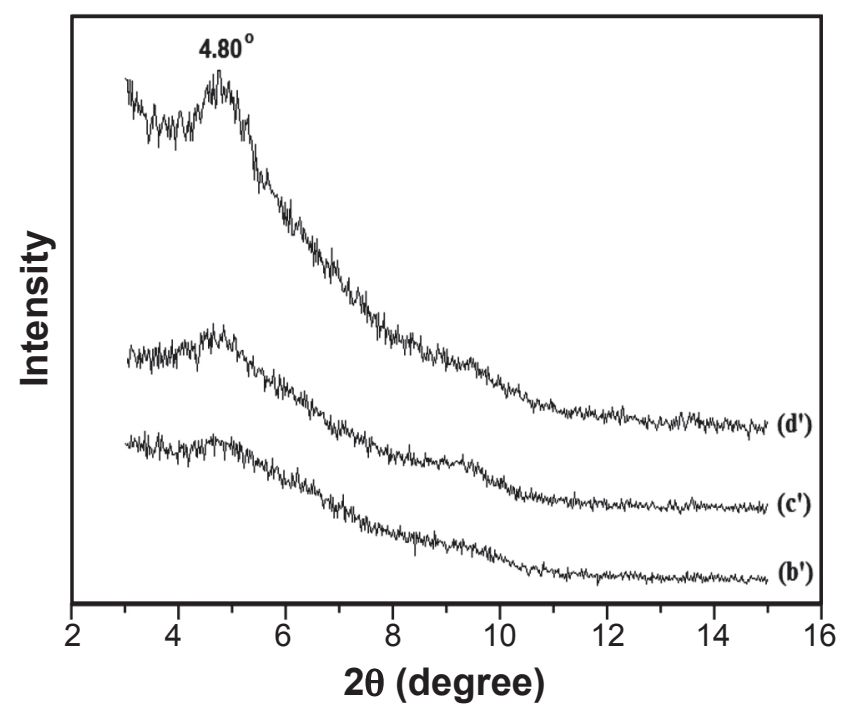

Figure 5: XRD patterns of pillared nontronite: (b') natural nontronite, (c') sodic nontronite and (d') sodic nontronite treated with sodium hypochloride.

[Figura 5: Difratogramas de raios X da nontronita pilarizada: (b') nontronita natural, (c') nontronita sódica e (d') Nontronita tratada com hipoclorito de sódio, sódica e pilarizada.]

Aluminium-lanthanum intercalated and pillared nontronite: since the best results for pillared clay came from the ones treated with $\mathrm{NaOCl}$ and $\mathrm{NaCl}$ solutions, the pillared clay doped with lanthanum followed the same procedure, with lanthanum and aluminium with proportion of 1:10. The X-ray diffraction pattern showed in Fig. 6 presents peaks in lower angle at $7.0^{\circ}$ shifted to $4.8^{\circ}$ as consequence of the plane (001) expansion, caused by the introduction of the polyhydroxi cationdoped with lanthanum, resulting in a interlayer distance of $18.40 \AA$ [30].

After thermal treatment to obtain the pillared material, the X-ray diffraction pattern shows that peaks lowered intensity with an increase in basal space, that should be consequence of the polyhydroxication dehydroxylation when the pillar was forming, Fig. 7. The behaviour presented by the intercalated clay during the thermal process is related to the distribution of the ions that will form the pillars, if the distribution is irregular, the pillars will fall and the structure will collapse. The pillar distribution is related to the ionic homogeneity and the exfoliation degree during the process of intercalation.

The isoelectronic potential data show that clay particle presents flocculation between $\mathrm{pH} 4.0$ and 5.0. The intercalating solutions presented $\mathrm{pH}$ between 3.5 for aluminium-lanthanum and 3.8 for aluminium oligomers, respectively. As consequence, the solution containing alumina oligomers would be subjected to an environment that

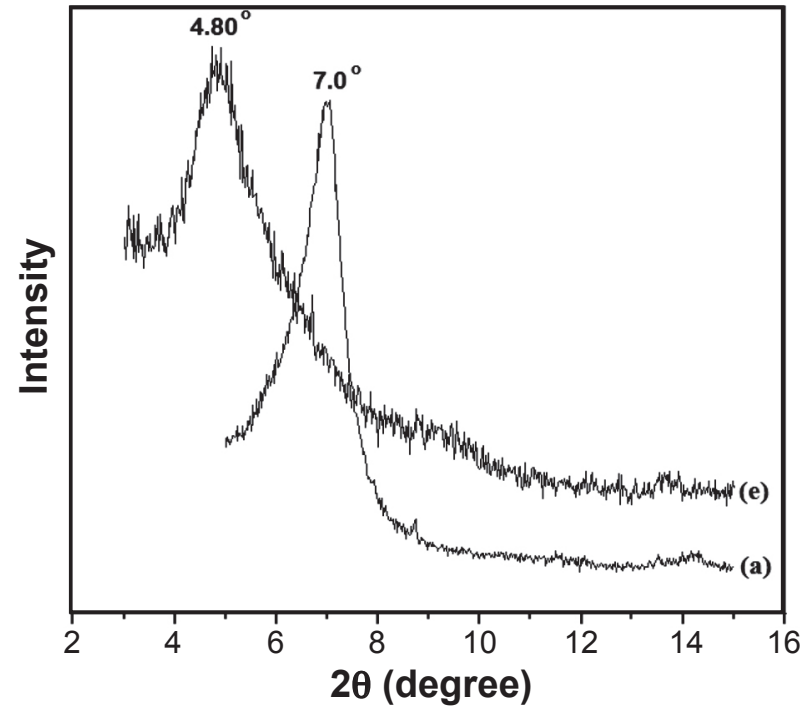

Figure 6: XRD patterns: (a) natural nontronite; (e) intercalated nontronite with AlLa.

[Figura 6: Difratogramas de raios X: (a) nontronita natural; (e) nontronita intercalada com AlLa.]

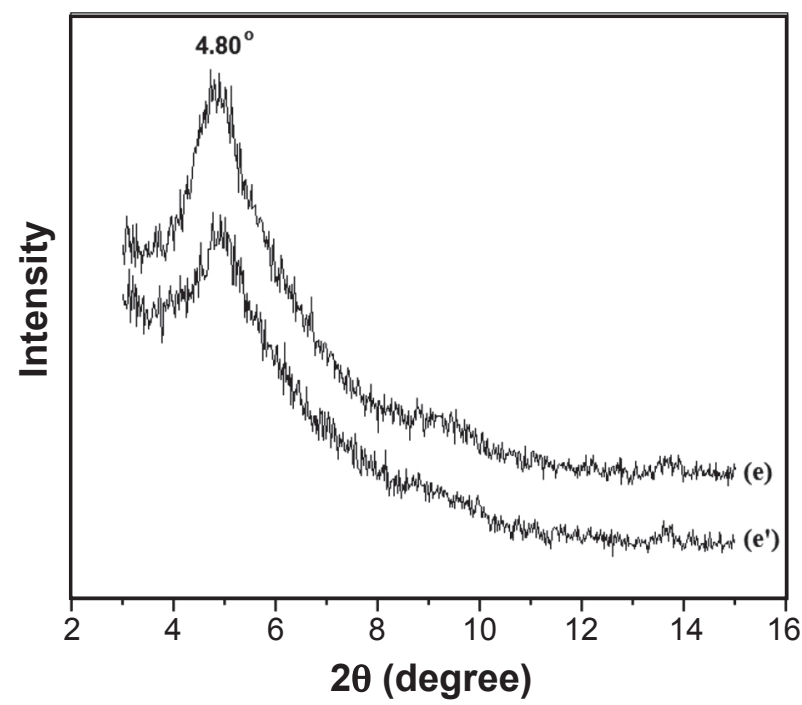

Figure 7: XRD patterns of nontronite: (e) intercaled with AlLa; (e') pillared with AlLa.

[Figura 7: Difratogramas de raios X da nontronita: (e) intercalada com AlLa; (e') pilarizada com AlLa.]

Table II - Structural parameters of modified nontronite. [Tabela II - Parâmetros estruturais da nontronita modificada.]

\begin{tabular}{ccccc}
\hline $\begin{array}{c}\text { Intercalated } \\
\text { clay }\end{array}$ & $\begin{array}{c}\mathrm{d}_{\mathrm{O}_{01}}(\AA) \\
(\AA)\end{array}$ & $\begin{array}{c}\text { Peak height } \\
\text { (counts) }\end{array}$ & $\begin{array}{c}\text { half width } \\
\left({ }^{\circ} 2 \theta\right)\end{array}$ & $\begin{array}{c}\text { Peak area } \\
\text { (u.a) }\end{array}$ \\
\hline e & 18.40 & 395 & 1.10 & 434 \\
e' & 17.95 & 266 & 1.07 & 285 \\
d' & 18.60 & 359 & 1.04 & 373 \\
\hline
\end{tabular}


could promote flocculation, less exfoliation and intercalation with the oligomer occurring in a lesser proportion resulting in a pillared solid not so thermal resistant. Table II shows the structural parameters for intercalated and pillared nontronite with lanthanum doped alumina. For comparisons, Table II also shows the parameters presented by alumina-pillared clay (d').

Pillared nontronite and its acid strength: the main reason to produce pillared clay with pillars containing aluminiumlanthanum cations is to produce surface modification and improve its thermal stabilities with increased acidic property [15]. Ammonium ion is used as probe, in DSC experiments, to quantify the acid strength on the alumina and aluminalanthanum pillars, the Fig. 8 shows the DSC curves resulted from nontronite clays.

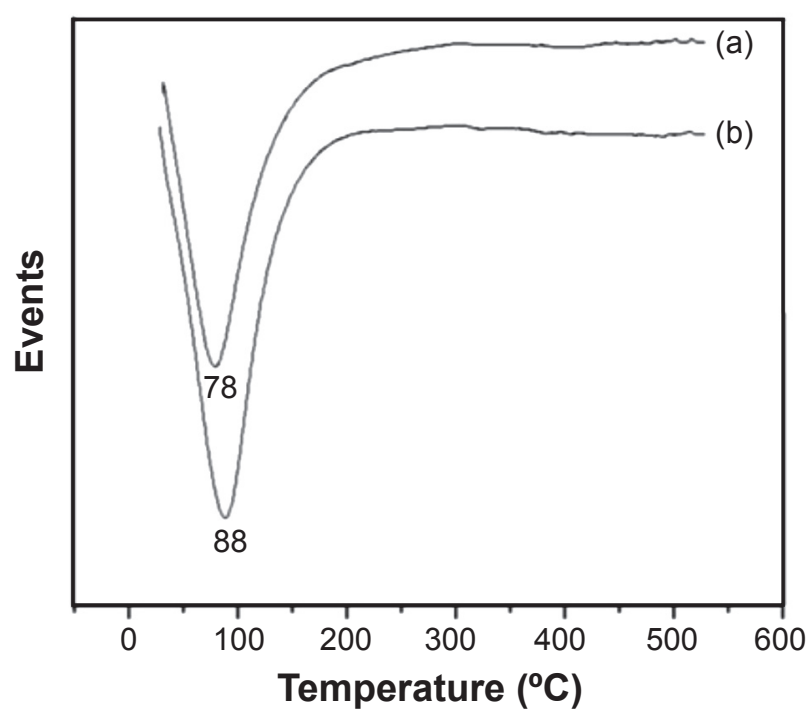

Figure 8: DSC curves of pillared nontronite with: (a) aluminum and (b) aluminum-lanthanum.

[Figura 8: Curvas DSC da nontronita pilarizada com (a) alumínio e (b) aluminio-lantânio.]

The DSC results showed that an exothermic event between $50^{\circ} \mathrm{C}$ and $200{ }^{\circ} \mathrm{C}$ is due to the break of ammonia bond occurring at $78{ }^{\circ} \mathrm{C}$ for pillared clay with aluminium and in $88{ }^{\circ} \mathrm{C}$ for pillared clay with aluminium-lanthanum. This difference of $10^{\circ} \mathrm{C}$ shows that ammonia interacts more effectively with the pillared clay containing the lanthanum, possibly due to the enhanced acidity. The peak area can be related with the number of active sites on the material. According with the results, Table III, the lanthanum

Table III - DSC data of the samples pillared clay.

[Tabela III - Dados de DSC das amostras argila pilarizada.]

\begin{tabular}{cccc}
\hline Pillared clay & $\begin{array}{c}\text { Maximum peak } \\
\left({ }^{\circ} \mathrm{C}\right)\end{array}$ & $\begin{array}{c}\text { Area } \\
(\text { a.u. })\end{array}$ & $\begin{array}{c}\text { half width } \\
\left({ }^{\circ} \mathrm{C}\right)\end{array}$ \\
\hline $\mathrm{H}^{+} / \mathrm{Al}$ - Pilm & 80 & 114 & 57 \\
$\mathrm{H}^{+} / \mathrm{AlLa}$ - Pilm & 89 & 169 & 61 \\
\hline
\end{tabular}

incorporation increases significantly the amount of acid sites.

Pillared clay and catalysis applications: the reaction condition, used here, was adopted after some preliminary tests on the zeolite Y, one pure sample and another sample containing platinum at 1 mass $\%$. These materials were taken as reference as they are used as solid catalyst in industries. The results on Figs. 9 thru 11 present the catalytic behaviour observed for samples of zeolite Y. Fig. 9 presents the n-octane conversion using the sample Pt-Y as function of temperature. This study tells us that the best range of temperature to be used in the catalytic test. Its determination is necessary to normalise the percentage of conversion. The profile presented on Fig. 9 points to $300{ }^{\circ} \mathrm{C}$ as the working temperature.

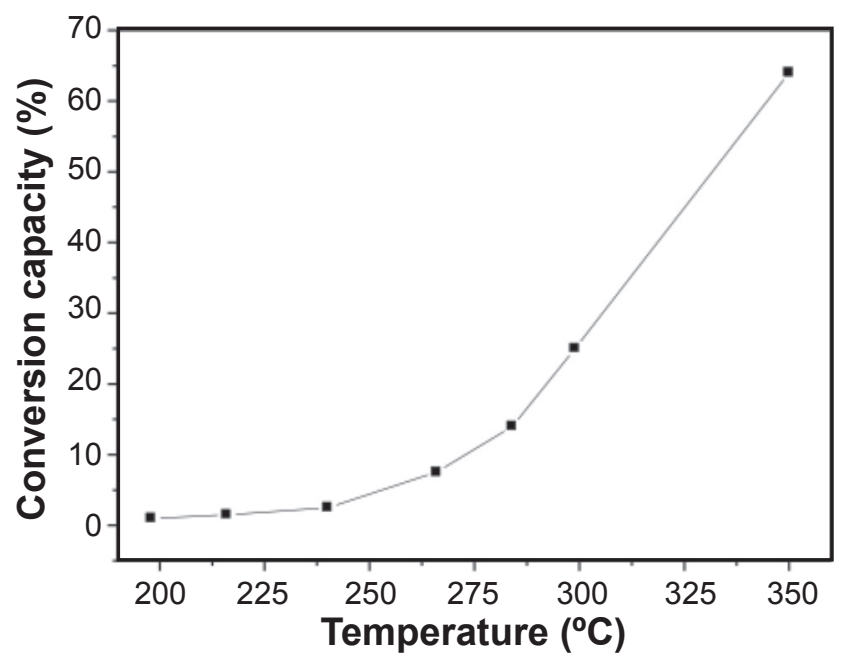

Figure 9: The effect of temperature over the conversion capacity of n-octane for Pt-Y activated at $350{ }^{\circ} \mathrm{C} / 1 \mathrm{~h}$ under $\mathrm{H}_{2}$.

[Figura 9: Efeito da temperatura sobre a capacidade de conversão de n-octano para Pt-Y ativado a $350{ }^{\circ} \mathrm{C} / 1$ h sob $\mathrm{H}_{2}$.]

The catalytic test with fresh sample at $300{ }^{\circ} \mathrm{C}$ was performed to verify the possible decrease in the conversion rate of n-octane in a time frame of $6 \mathrm{~h}$ under constant flow. Fig. 10 presents the results of the reaction system after $6 \mathrm{~h}$ showing stability of $30 \%$ on n-octane conversion and selectivity around $70 \%$.

Verify the importance of platinum in the catalyst composition, one test was performed with the Y sample under the same conditions. The profile presented on Fig. 11 shows that at the beginning occurs higher conversion; however, the decrease in conversion after $2 \mathrm{~h}$ followed by values compared to the sample Pt-Y. The selectivity, on the other hand, was different with negligible values to the isomerization products.

Based on the catalytic behaviour presented by Pt-Y, together with the flow and reactant conditions, the catalytic tests were performed using pillared clay at $300{ }^{\circ} \mathrm{C}$ for $400 \mathrm{~min}$.After the activation process at $300{ }^{\circ} \mathrm{C}$ under hydrogen atmosphere for $1 \mathrm{~h}$, the catalytic sample Pt/AlPilM ( $1 \%$ in mass, impregnated platinum in pillared clay) 


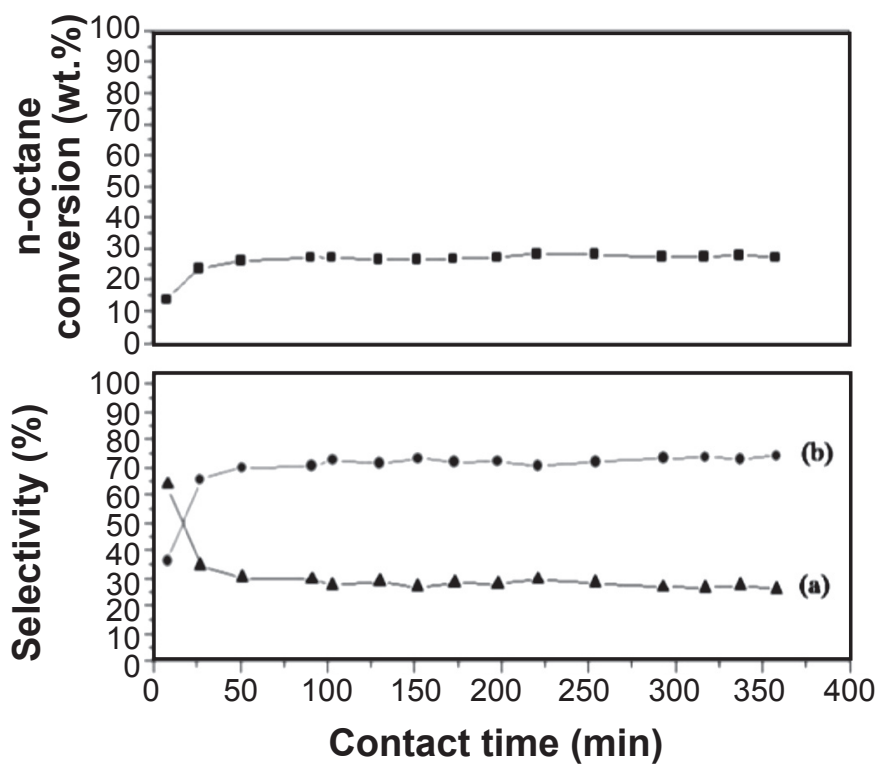

Figure 10: Conversion capacity and selectivity for $\mathrm{f} \mathrm{Pt-Y}$ activated at $350{ }^{\circ} \mathrm{C} / 1 \mathrm{~h}$ under $\mathrm{H}_{2}$. (a) cracking products and (b) isomerization products.

[Figura 10: Capacidade de conversão e seletividade para Pt-Y ativado a $350{ }^{\circ} \mathrm{C} / 1 \mathrm{~h}$ sob $\mathrm{H}_{2}$. (a) produtos de craqueamento e (b) produtos de isomerização.]

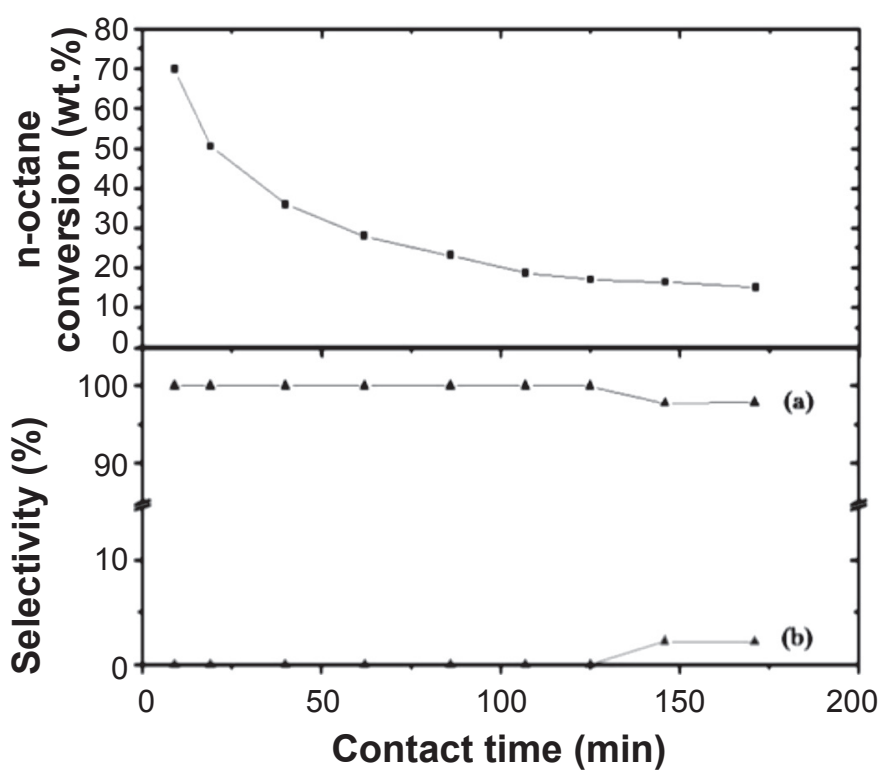

Figure 11: Conversion capacity and selectivity for zeolite $\mathrm{Y}$ activated at $350{ }^{\circ} \mathrm{C} / 1 \mathrm{~h}$ under $\mathrm{H}_{2}$. (a) cracking products and (b) isomerization products.

[Figura 11: Capacidade de conversão e seletividade para zeólita Y ativada a $350{ }^{\circ} \mathrm{C} / 1 \mathrm{~h} \mathrm{sob} \mathrm{H}_{2}$. (a) produtos de craqueamento e (b) produtos de isomerização.]

was subjected to the catalytic test, and the results are shown in Fig. 12. The maximum conversion capacity observed was around of $70 \%$ with decrease to $60 \%$ after $4 \mathrm{~h}$ of reaction and keeping steady until the end of the experiment. The conversion tax presented for Pt/Al-PilM was twice of that presented for Pt-Y, maintaining the global selectivity index

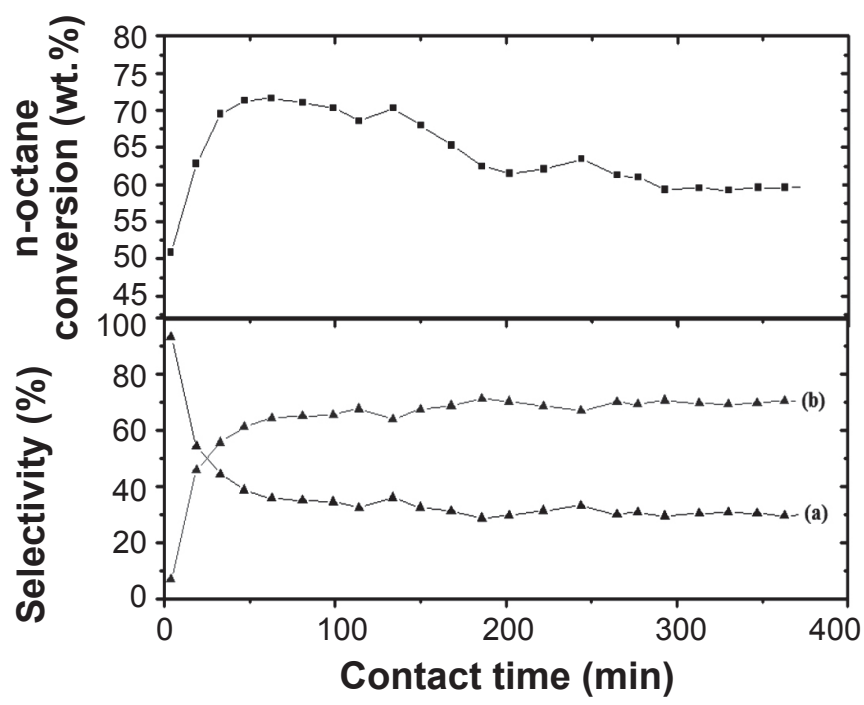

Figure 12: Conversion capacity and selectivity for $\mathrm{Pt} / \mathrm{Al}$ Pilm activated at $350{ }^{\circ} \mathrm{C} / 1 \mathrm{~h}$ under $\mathrm{H}_{2}$. (a) cracking products and (b) isomerization products.

[Figura 12: Capacidade de conversão e seletividade para Pt/Al-Pilmativada a $350{ }^{\circ} \mathrm{C} / 1 \mathrm{~h}$ sob $\mathrm{H}_{2}$. (a) produtos de craqueamento e (b) produtos de isomerização.]

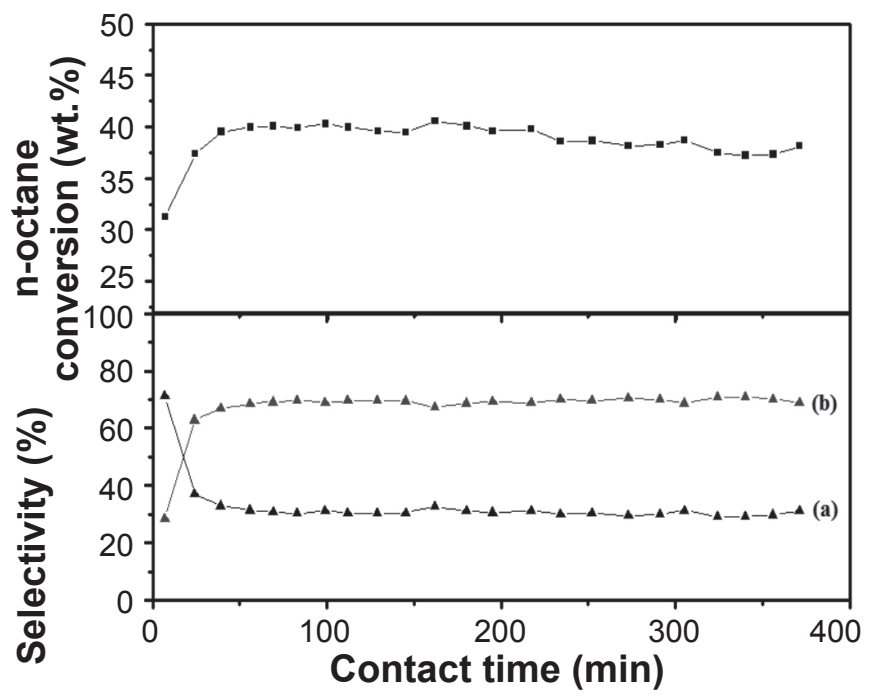

Figure 13: Conversion capacity and selectivity for Pt/AlLaPilm activated at $350{ }^{\circ} \mathrm{C} / 1 \mathrm{~h}$ under $\mathrm{H}_{2}$. (a) cracking products and (b) isomerization products.

[Figura 13: Capacidade de conversão e seletividade para Pt/AlLa-Pilm ativada a $350{ }^{\circ} \mathrm{C} / 1 \mathrm{~h} \mathrm{sob} \mathrm{H}_{2}$. (a) produtos de craqueamento e (b) produtos de isomerização.]

for isomerisation near $70 \%$. This fact points to potential applications of catalytic material of this kind.

To verify the contribution of the lanthanum oxide on the catalytic selectivity and the stability, new pillared clay containing platinum and lanthanum was prepared and the catalytic behaviour is shows in Fig. 13. As observed, the presence of lanthanum reduces 30\% the conversion capacity of the n-octane compared with the catalyst with no lanthanum. On the other hand, the presence of lanthanum 
does notaffect the global selectivity of the isomerization products of $70 \%$.

\section{CONCLUSIONS}

The nontronite pillaring with aluminium polyhydroxications and aluminium-lanthanum presented different chemical and structural properties. The tests on pillared nontronite showed that the number of acid Lewis sites and the acid strength increase with lanthanum incorporation. The catalytic test on the hydroisomerization of n-octane showed that pillared clay with aluminium presented superior conversion when compared with the aluminium-lanthanum material. The conversion capacity was $70 \%$ up to $150 \mathrm{~min}$ of reaction and then it lowered to $60 \%$ until the end of the observation. With the sample containing aluminium-lanthanum, the conversion did not alter and kept around $40 \%$. When comparing the results for zeolite Y $(30 \%)$, both clays showed to be effective in this transformation. However, the selectivity was comparable and around $70 \%$ on iso-alcane (isomerization) products and $30 \%$ on cracking derivatives.

\section{ACKNOWLEDGEMENTS}

The authors gratefully acknowledge financial support from CAPES and CNPq.

\section{REFERENCES}

[1] F.C.A. Figueiredo, E. Jordão, W.A. Carvalho, Appl. Catal. A: General 351 (2008) 259-266.

[2] T. Baskaran, J. Christopher, T. G. Ajithkumar, S. Ayyamperumal, Appl. Catal. A: General 488 (2014) 119127.

[3] A. Lucas, M.J. Ramos, F. Dorado, P. Sánchez, J.L. Valverde, Appl. Catal. A: General 289 (2005) 205-213.

[4] J. Li, Y. Chai, B. Liu, Y. Wu, X. Li, Z. Tang, Y. Liu, C. Liu, Appl. Catal. A: General 469 (2014) 434-441.

[5] S. Arfaoui, E. Srasra, N. Frini-Srasra, Desalination Environment 185 (2005) 419-426.

[6] M. Due, F. Gaboriaud, F. Thomas, J. Colloid Interface Sci.289 (2005) 139-147.

[7] M. Akçay, Appl. Catal. A: General 269 (2004) 157-160.

[8] J. Carriazo, E. Guélou, J. Barrault, J.M. Tatibouët, R. Molina, S. Moreno, Catalysis Today 107-108 (2005) 126-132.
[9] Y.-X. Jiang, X.-M. Chen, Y.-F. Mo, Z.-F. Tong, J. Molecular Catalysis A: Chemical 213 (2004) 231-234.

[10] F.J. Luma, U. Schuchardt, Quim. Nova 22 (1999) 104109.

[11] A.C.V. Coelho, P.S. Santos, Bol. Tec. Petrobrás 31 (1988) 143-157.

[12] O. Macias, J. Largo, C. Pesquera, C. Blanco, F. González, Appl. Catal. A: General 314 (2006) 23-31.

[13] Ho Jeong Chae, In-Sik Nam, Sung Won Ham, Suk Bong Hong, Catalysis Today 68 (2001) 31-40.

[14] A. Aznárez, S. A. Korili, A. Gil, Appl. Catal. A: General 474 (2014) 95-99.

[15] G. Del Angel, C. Guzmán, A. Bonilla, G. Torres, J.M. Padilla, Mater. Lett.59 (2005) 499-502.

[16] C.F. Gomes, "Argilas - O que são e para que servem", Fundação Calouste Guilbenkian, Lisboa, Portugal (1986).

[17] F.J. del Rey-Perez-Caballero, G. Poncelet, Microporous Mesoporous Mater.37 (2000) 313-327.

[18] L. D. V. Abreu, Estudo da pilarização com alumina, de argilas esmectitas brasileiras, Eng. Química, Escola Politécnica da Universidade de S. Paulo, S. Paulo, SP (1997) 128 in Portuguese.

[19] I. Mrad, A. Ghorbel, D. Tichit, J.F. Lambert, Appl. Clay Sci.12 (1997) 349-364.

[20] D. Dinger, Ceram. Ind.11 (2006) 23-30.

[21] R. Mahboub, Y. El Mouzdahir, A. Elmchaouri, A. Carvalho, M. Pinto, J. Pires, Colloids Surfaces A: Physicochem. Eng. Aspects 280 (2006) 81-87.

[22] G. Chigwada, D. Wang, D.D. Jiang, C.A. Wilkie, Polymer Degradation Stability 91 (2006) 755-762.

[23] S. Vreysen, A. Maes, Appl. Clay Sci. 32 (2006) 283290.

[24] M.L. Occelli, A. Auroux, G.J. Ray, Microporous Mesoporous Mater. 39 (2000) 43-56.

[25] B. Velde, Introduction to Clay Minerals, Chapman \& Hall, London, UK (1992).

[26] S.Q. M. Leite, L. C. Dieguez, R.A.S. San Gil, S.M.C. de Menezes, Quim. Nova 23 (2000) 149-153.

[27] S.B.C. Pergher, Quim. Nova22 (1999) 649-653.

[28] N.D. Hutson, M. J. Hoekstra, R. T. Yang, Microporous Mesoporous Mater.28 (1999) 447-459.

[29] J.T. Kloprogge, R. Evans, L. Hickey, R.L. Frost, Appl. Clay Sci.20 (2002) 157-163.

[30] A. Gil, L.M. Gandía, M.A. Vicente, Catal. Rev - Sci. Eng.42 (2000) 145-212.

(Rec. 30/01/2015, Ac.03/07/2015) 